\title{
Statement of Ownership, Management, and Circulation
}

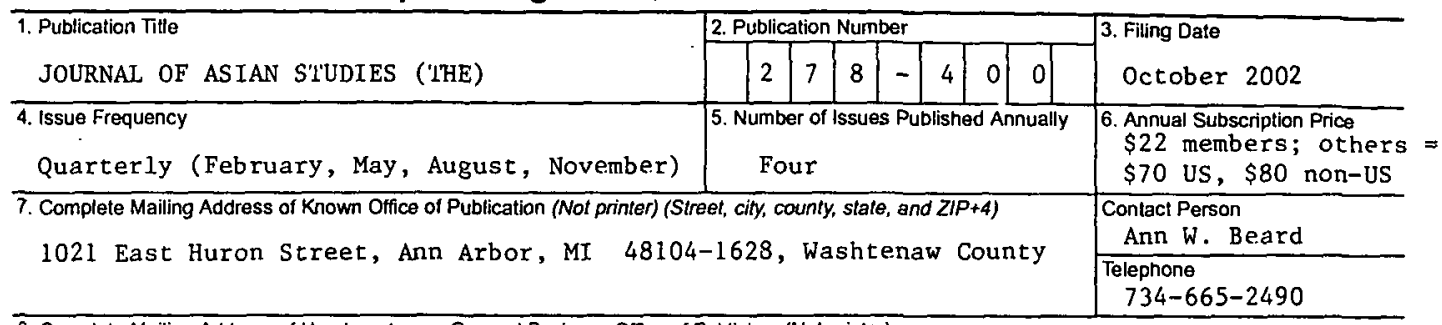

8. Complete Mailing Address of Headquarters or General Business Office of Publisher (Not printer)

Same as Above

9. Full Names and Complete Mailing Addresses of Publisher, Editor, and Managing Editor (Do not leave blank)

Publisher (Name and complete mailing address)

Association for Asian Studies, 1021 East Huron Street, Ann Arbor, MI 48104-1628

Editor (Name and complete mailing address)

Ann Waltner, Department of History, University of Minnesota, Minneapolis, MN 55455

Managing Editor (Name and complete mailing address)

Same as Above

10. Owner (Do not leave blank. If the publication is owned by a corporation, give the name and address of the corporation immediately followed by the names and addresses of all stockholders owning or holding 1 percent or more of the total amount of stock. If not owned by a corporation, give the each individual owner, If the publication is published by a nonprofit organization, give its name and address.)

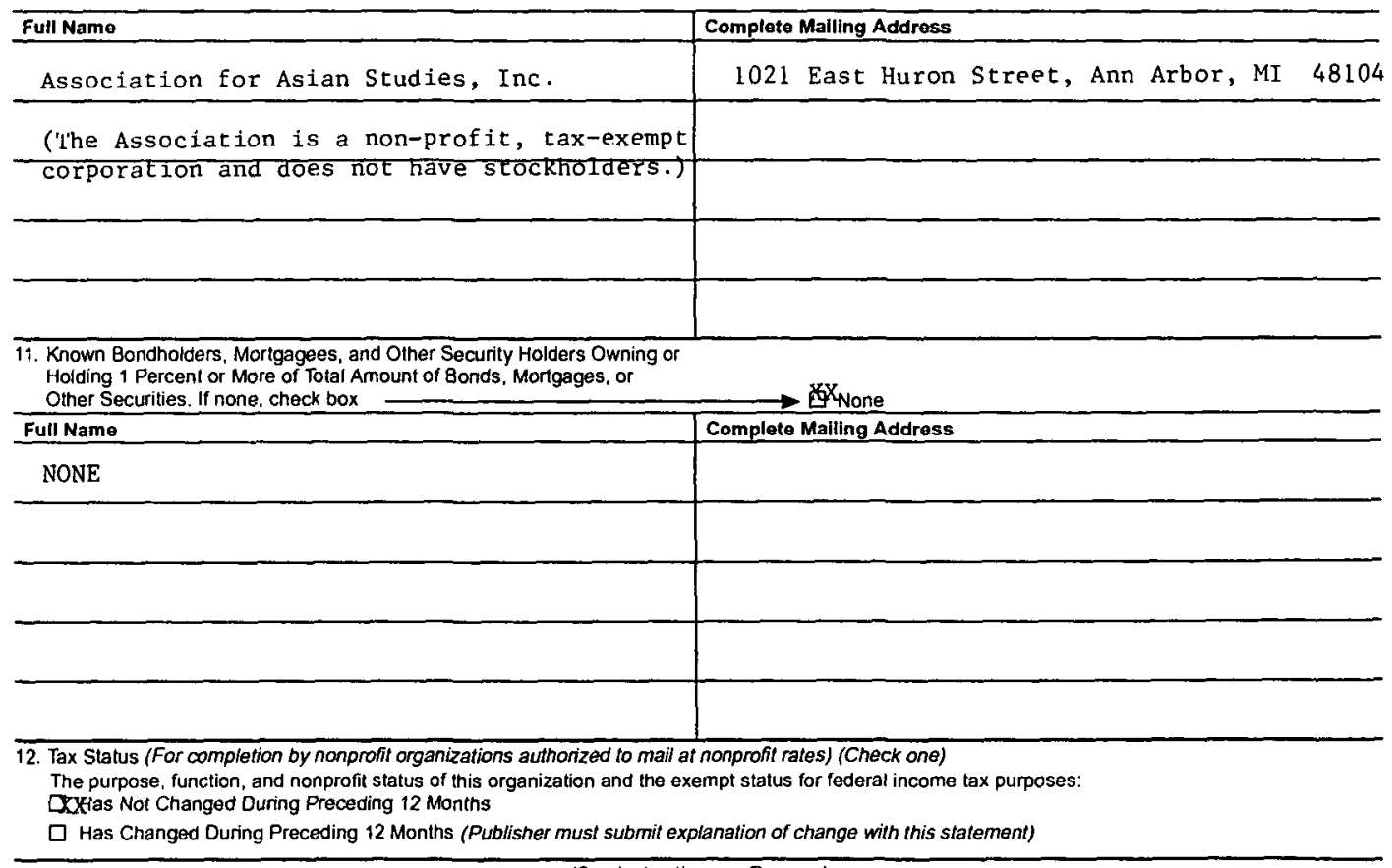




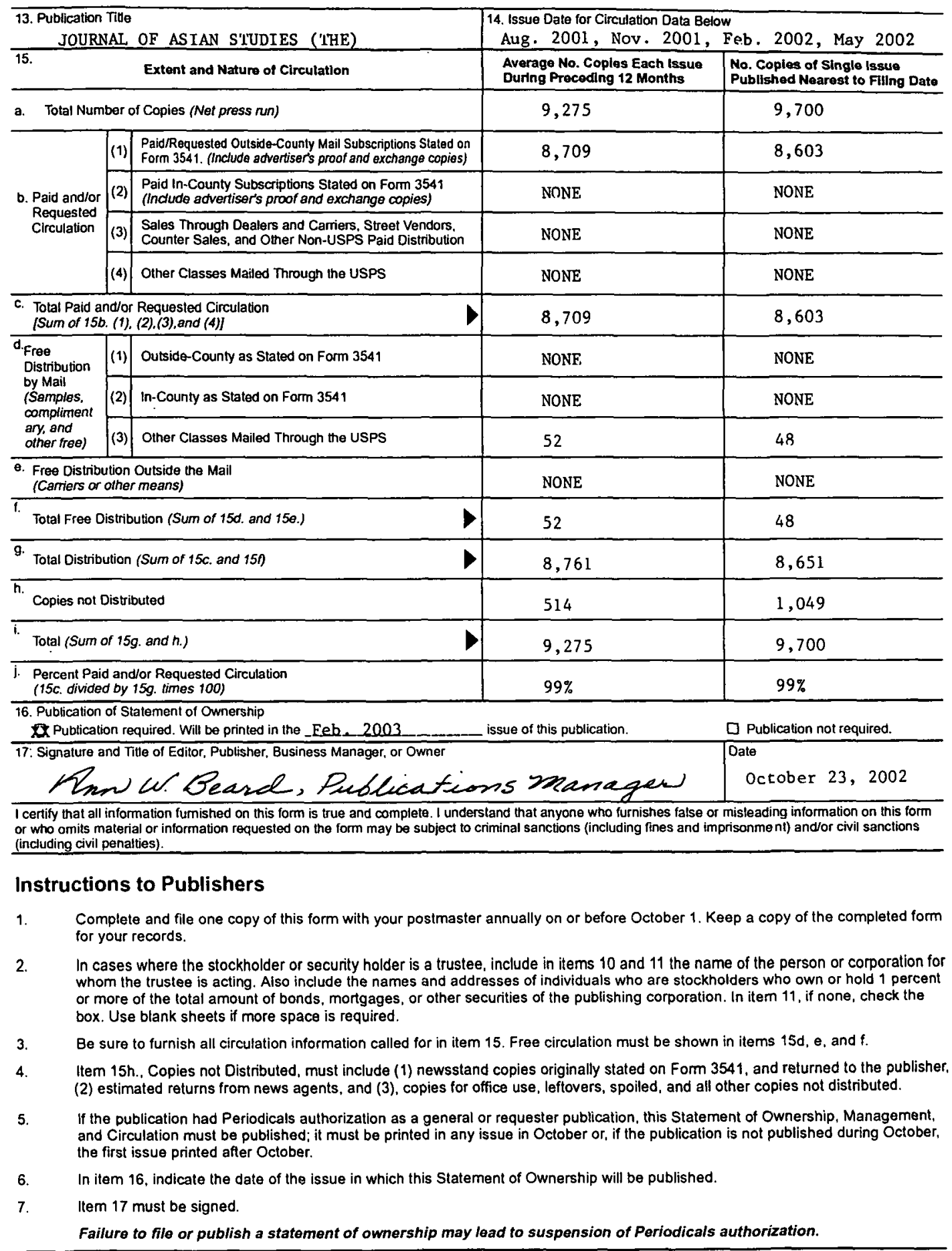

PS Form 3526, October 1999 (Reverse) 


\section{Diem's Final Failure}

\section{Prelude to America's War in Vietnam}

Philip E. Catton

"A fresh and provocative look at a neglected but crucial period during the Vietnam War. Catton's penetrating study explodes the contrasting portrayals of Ngo Dinh Diem as villain or savior to present a more nuanced view of one of the war's most tragic figures."-William J. Duiker, author of Ho Chi Minh: A Life Modern War Studies

280 pages, 20 photographs, Cloth $\$ 34.95$

\section{Decent Interval}

An Insider's Account of Saigon's Indecent End Told by the CIA's Chief Strategy Analyst in Vietnam

\section{Twenty-Fifth Anniversary Edition}

\section{Frank Snepp}

With a new foreword by Gloria Emerson

"A great service to everyone's understanding of what happened in Vietnam in the spring of 1975 . . . Other accounts of that time will have to be measured against what Snepp, from his unique and highly informed vantage point, has produced."

-Kevin Buckley, New York Times Book Review

636 pages, 35 photographs, Paper $\$ 24.95$

\section{The Vietnam War on Trial}

\section{The My Lai Massacre and the Court-Martial of}

\section{Lieutenant Calley}

Michal R. Belknap

"A wise, discerning, and powerful account of a notable trial that illuminates the larger meaning of the Vietnam War. Belknap's extraordinary analysis of the My Lai story skillfully explores the atrocities, the cover-up, and the political manipulation of the affair, and takes us beyond contemporary journalism to the complex history of what happened-and why."-Stanley Kutler, author of The Wars of Watergate Landmark Law Cases and American Society 272 pages, Cloth $\$ 35.00$, Paper $\$ 15.95$
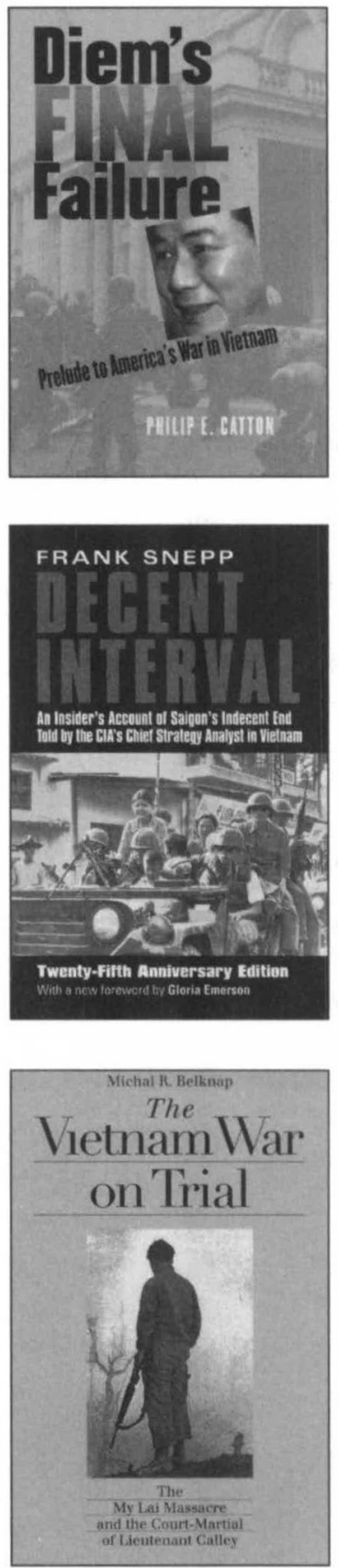

Available at bookstores or from the press. VISA and MasterCard accepted.

\section{University Press of Kansas}

2501 West 15th Street • Lawrence KS 66049 Phone (785) 864-4155 • Fax (785) 864-4586 www.kansaspress.ku.edu 


\section{PAMPER YOUR INTELLECT}

The United States in the Asia-Pacific since 1945

Roger Buckley

0-521-80964-9 Hardback $\$ \$ 65.00$

0-521-00725-9 Paperback $\$ 23.00$

Financial Crisis and

Transformation of

Korean Business Groups

The Rise and Fall of Chaebols

Sea-jin Chang

0-521-81435-9 Hardback $\$ 75.00$

\section{Banking in Modern China}

Entrepreneurs, Professional Managers and the Development of Chinese Banks,

1897-1937

Linsun Cheng

Cambridge Modern China Series

0-521-81142-2 Hardback $\$ 65.00$

China Since Tiananmen

The Politics of Transition

Joseph Fewsmith

Cambridge Modern China Series

0-521-80634-8 Hardback $\$ 60.00$

0-521-00105-6 Paperback $\$ 22.00$

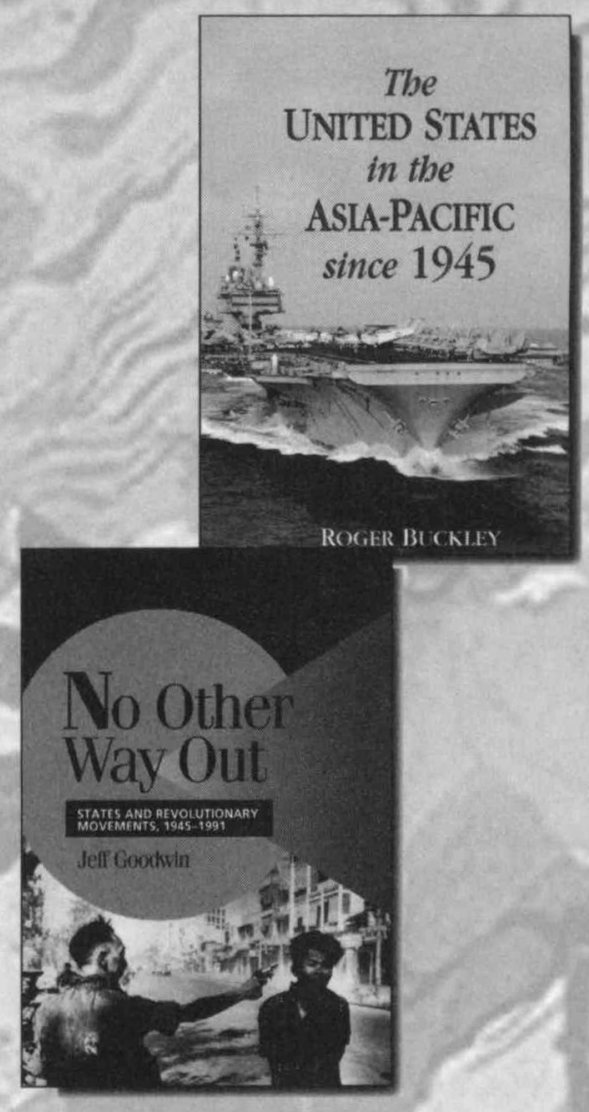

Family and Social Policy

in Japan

Anthropological Approaches

Roger Goodman, Editor

Contemporary Japanese Society

0-521-81571-1 Hardback $\$ 60.00$

0-521-01635-5 Paperback $\$ 22.00$

\section{No Other Way Out}

States and Revolutionary Movements,

1945-1991

Jeff Goodwin

Cambridge Studies in Comparative Politics

0-521-62069-4 Hardback $\$ \$ 60.00$

0-521-62948-9 Paperback $\$ 23.00$

Economic Crisis and Corporate Restructuring in Korea

Reforming the Chaebol

Stephan Haggard, Wonhyuk Lim, and Euysung Kim, Editors

Cambridge Asia-Pacific Studies

0-521-82363-3 Hardback

$\$ 60.00$

Asia-Pacific

\section{Constitutional Systems}

Graham Hassall and

Cheryl Saunders

Cambridge Asia-Pacific Studies

0-521-59129-5 Hardback 


\section{WITH CAMBRIDGE BOOKS}

Crisis and Innovation in Asian Technology

William W. Keller and

Richard J. Samuels, Editors

0-521-81871-0 Hardback $\$ 75.00$ 0-521-52409-1 Paperback \$27.00

Theorizing

Chinese Masculinity

Society and Gender in China

Kam Louie

0-521-80621-6 Hardback $\$ 55.00$

Feminism in Modern Japan

Citizenship, Embodiment and

Sexuality

Vera Mackie

Contemporary Japanese Society

0-521-82018-9 Hardback $\$ 70.00$

0-521-52719-8 Paperback $\$ 25.00$

China in the World Market

Chrinese Industry and

International Sources of Reform in the

Post-Mao Era

Thomas G. Moore

Cambridge Modern China Series

0-521-66283-4 Hardback $\$ 65.00$

0-521-66442-X Paperback $\$ 24.00$

The Sino-Japanese

War of 1894-1895

Perceptions, Power and Primacy

S.C.M. Paine

0-521-81714-5 Hardback $\$ 55.00$

Hindu Kingship and Polity in

Pre-Colonial India

Norbert Peabody

Cambridge Studies in Indian History and Society 9

0-521-46548-6

Hardback

$\$ 55.00$

's Long March toward

Rule of Law

Randall Peerenboom

0-521-81649-1 Hardback $\$ \$ 110.00$

0-521-01674-6 Paperback $\$ 40.00$

\section{Changing India}

Bourgeois Revolution on the

Subcontinent

Second Edition

Robert W. Stern

0-521-81080-9

Hardback $\$ 60.00$

THE SINO-JAPANESE

WAR OF 1894-1895

PERCLPTIONS. POWER.

IND PRIILCY

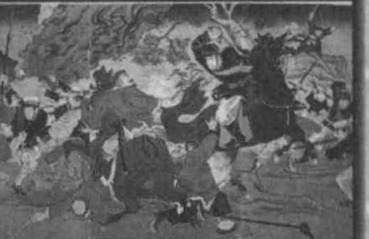

S. C. M. PAINE
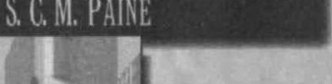

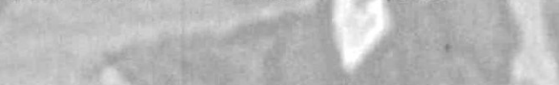




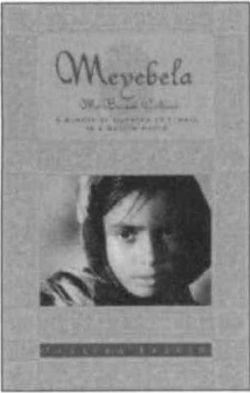

Meyebela: My Bengali Girlhood

A memoir of Growing up Female in a Muslim World

by Taslima Nasrin

Cloth

ISBN: $1-58642-051-8$

$\$ 26.00$

"I believe Nasrin's Meyebela will, like Huckleberry Finn, become a classic of controversy, hated, loved, banned, made a school text, removed from the schools and fought over as long as people read. . . Meyebela's bravery, vividness and groundbreaking subject matter make it a remarkable achievement, and one that will live."

$$
\text { -The Nation }
$$

Bengali dissident TASLIMA NASRIN has lived in Sweden since 1993 when a death fatwa placed by local clergy and a government arrest warrant caused her to flee her native country.

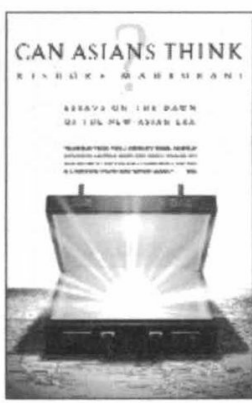

Can Asians Think?

Understanding the Divide Between East and West

by Kishore Mahbubani

Cloth

ISBN: 1-58642-033-X

$\$ 14.00$

"Mahbubani's aim is to open the dialogue - particularly in the aftermath of September II, when the frequently asked question, 'Why do they hate us' displayed as much ignorance as anguish. Mahbubani's eloquent ideas attempt to bridge that glaring gap in information and perspective." - The Seattle Times

KISHORE MAHBUBAN1, who has studied philosophy in Asia and North America, is in his second term as Singapore's ambassador to the U.N.

\section{New and Notable in Asian Studies from Indiana University Press}
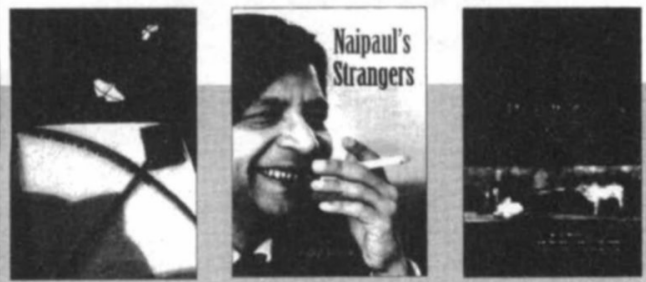

\section{THE PARITIIONS OF MEMORY}

\section{The Afferitife of the Ditistion of India}

Edited by Survir Kaul

An exploration of representation, memory, and the continuing effects of Partibion in contemporary India and Pakisten. Echoes of the traumatic events surrounding the Partiton of India in 1947 can be heard to this day in the daily life of the subcontinent each time India and Pakistan play a cricket match or when their political leaders speak of "unfinished business."

2002 paper $\$ 21.95$

\section{NAIPAUISS STRANGERS}

\section{Dagmar Barnour}

A masterfiul study of the cultural explorations of the Nobel Prize winning author

2003 doth $\$ 55.00$ paper $\$ 21.95$

\section{THE GIFT OF A COW}

A Thanslation of the Classic Hindi Novel Godaan

Premchand [Dhanpat Rai]

Translated by Gordon C. Roadarmel

This widely-praised translation of Premchand's most celebrated novel is now in a second edition, with a new introduction by Vasudha Dalmia An engeging introduction to north India before Independence, Godaan is at once village ethnography, moving human document, and insightful colonial history. 2002 paper $\$ 21.95$

\section{TRANSPORTS OF DELIGHT}

The Ricksha Arts of Bangladesb (CD-ROM)

Joanna Kirkpatrick

Acolorful multimedia exploration of folk art, culure, and religion. 2002 CD-ROM \$29.95

\section{PANDITA RAMABAIS AMERICAN ENCOUNIER}

\section{The Peoples of the United States (1899)}

Pandita Ramabai

Translated and edited by Meera Kosambi

An account of 19 th-century American life by a remarkable Indian observer 2003 doth $\$ 59.95$ paper $\$ 29.95$ 


\section{from EastGate 1 .}

\section{New! \\ Biographical Dictionary of Chinese Women}

The Twentieth Century, 1912-2000 Edited by Lily Xiao Hong Lee

Drawing on the enormous amount of historical material and scholarly research that has become available in the past few decades, this volume contains more than 250 biographies of women active from 1912 until 1990 , although many of the biographies include information current through 2000 .

672 pp. $\cdot 0798-0$ Cloth $\$ 109.95$

\section{Chinese Books and Documents in the Jesuit Archives in Rome: A Descriptive Catalogue Japonica-Sinica I-IV \\ Albert Chan, S.J.}

"[A]ny scholar who has worked with that rich collection of materials will know what a significant achievement this represents for the field. This is a work of the highest scholarly level and a lasting testament to Fr. Chan's service as a Jesuit and scholar."

- Sino-Western Cultural Relations Journal 672 pp. $\cdot 0828-6$ Cloth $\$ 152.95$

\section{Chinese Provincial Leaders} Economic Performance and Political Mobility Since 1949 Zhiyue Bo

Based on biographical data on more than 2,500 individuals in China's thirty provincial units from the beginning of the People's Republic in 1949 , this is the most comprehensive and systematic treatment of China's provincial leaders ever published.

200 pp. * 0916-9 Cloth \$74.95/1017-5 Paper \$28.95

\section{New edition! Directory of Officials and Organizations in China, 3 ED. Two-Volume SeT Malcolm L. Lamb}

This exhaustive cumulative guide covers changes in key personnel and administrative institutions in China from 1968 to the present, with new sections on trade organizations; special administrative regions; museums, libraries, and galleries; banks and insurance companies; and more.

Two-volume set $\cdot 1,900 \mathrm{pp} . \cdot 1020-5$ Cloth $\$ 350.00$

New!

North Korea Handbook

Edited by Yonhap News Agency, Seoul Translated by Monterey Interpretation and Translation Services,

Heung-kook Park, President

This comprehensive guide to North Korea covers politics, the economy, the military, education and culture, and provides many vital statistical data. As a special feature, the book includes a useful "who's who" section.

1,100 pp. $\cdot 10043$ Cloth $\$ 350.00$

\section{The Vietnamese War Revolution and Social Change in the Mekong Delta \\ Two-Volume Set \\ David Elliott}

This monumental work traces the war in Vietnam in a single province of the Mekong Delta over the period 1930-1975 through the eyes of the Vietnamese participants. This indispensible work closely examines provincelevel documentation that casts light on a number of historical controversies about the war.

Two-volume set $\cdot 1,400$ pp. $\cdot 0602-X$ Cloth $\$ 140.00$ 


\section{NEW PUBLICATIONS FROM THE Harvard University Asia Center}

\section{Allegories of Desire \\ Esoteric Literary Commentaries of Medieval Japan \\ Susan Blakeley Klein \\ 340 pp. cloth $\$ 42.50$ \\ Japanese Law in Context}

Readings in Society, the Economy, and Politics

Curtis J. Milhaupt, J. Mark Ramseyer, and Michael K. Young, editors

650 pp. paperback $\$ 40.00$ cloth $\$ 70.00$

\section{Minamata}

Pollution and the Struggle for

Democracy in Postwar Japan

Timothy S. George

400 pp. paperback $\$ 25.00$ cloth $\$ 45.00$

\section{To Become a God}

Cosmology, Sacrifice, and

Self-Divinization in Early China

Michael J. Puett

$375 \mathrm{pp}$. cloth $\$ 49.50$

\section{RETHINKING THE I898}

\section{Reform Period}

Political and Cultural Change in Late Qing China

Rebecca E. Karl and Peter Zarrow, editors 300 pp. cloth $\$ 45.00$

\section{Great Walls of Discourse} and Other Adventures in Cultural China

Haun Saussy

300 pp. paperback $\$ 19.95$ cloth $\$ 45.00$
The Making of

"SHINKOKINSHŪ"

Robert N. Huey

480 pp. cloth $\$ 49.50$

\section{EMOTIONS AT WORK}

Normative Control, Organizations, and Culture in Japan and America

Aviad E. Raz

300 pp. cloth $\$ 35.00$

Tears of Longing

Nostalgia and the Nation in

Japanese Popular Song

Christine R. Yano

250 pp. cloth $\$ 35.00$

\section{EMPEROR AND ARISTOCRACY}

IN JAPAN; 1467-1680

Resilience and Renewal

Lee Butler

420 pp. cloth $\$ 39.50$

On Sacred Grounds

Culture, Society, Politics, and the

Formation of the Cult of Confucius

Thomas A. Wilson, editor

430 pp. cloth $\$ 45.00$

Printing for Profit

The Commercial Publishers of Jianyang,

Fujian (11th-17th Centuries)

Lucille Chia

440 pp. cloth $\$ 50.00$

Distributed by Harvard University Press

US $8004482242 \quad$ www.hup.harvard.edu 


\section{NEW PUBLICATIONS FROM THE}

\section{Harvard University Asia Center}

Re-examining the Cold War

U.S.-China Diplomacy, 1954-1973

Robert S. Ross and

Jiang Changbin, editors

520 pp. paperback $\$ 25.00$ cloth $\$ 60.00$

The Appropriation

of Cultural Capital

China's May Fourth Project

Milena Doleželová-Velingerová and

Oldřich Král, editors

360 pp. cloth $\$ 45.00$

\section{INKLINGS OF Democracy \\ IN China}

Suzanne Ogden

435 pp. paperback $\$ 19.95$ cloth $\$ 49.50$
In Search of Justice

The 1905-1906 Chinese

Anti-American Boycott

Guanhua Wang

250 pp. cloth $\$ 39.50$

The Golden Age of the

U.S.-ChINa-Japan

Triangle, 1972-1989

Ezra F. Vogel, Yuan Ming, and Tanaka Akihiko, editors 280 pp. cloth $\$ 65.00$

The Book of Korean SHijo

Kevin O'Rourke

250 Pp. cloth $\$ 35.00$

\section{Now Available in Paperback}

Poverty, Equality, AND

GrowTH: The Politics of

Economic Need in Postwar Japan

Deborah J. Milly

416 pp. paperback $\$ 24.95$

The People's Emperor

Democracy and the Japanese

Monarchy, 1945-1995

Kenneth J. Ruoff

340 pp. paperback $\$ 24.95$
In Pursuit of Status

The Making of South Korea's

"New" Urban Middle Class

Denise Porrzeba Letr

270 pp. paperback $\$ 19.95$

Poetry and Painting

In Song China

The Subtle Art of Dissent

Alfreda Murck

425 Pp. 44 illus. paperback $\$ 25.00$

Distribured by Harvard Universiry Press

US $8004482242 \quad$ www.hup.harvard.edu 


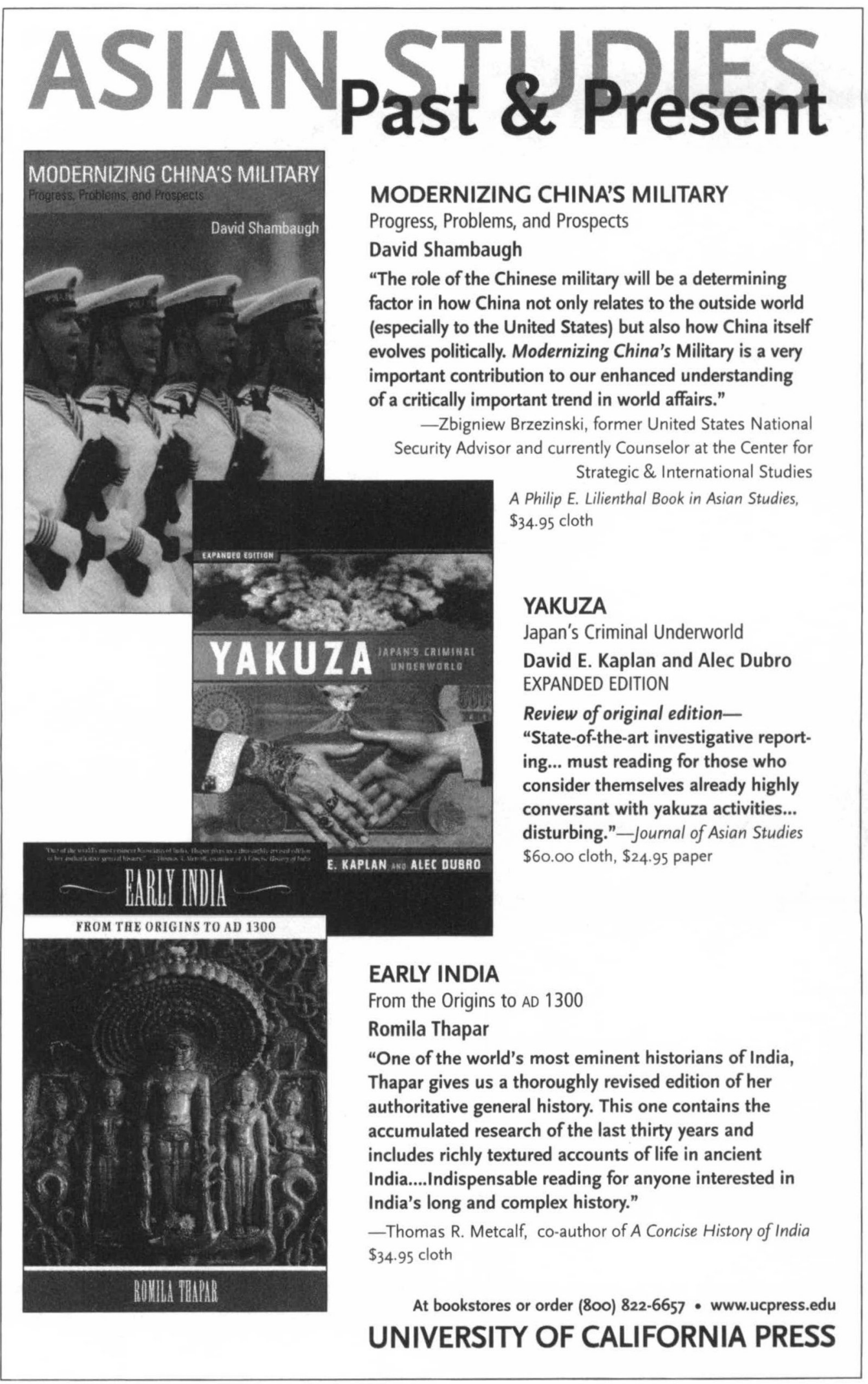




\section{ASIAN PST \& \& Present}

\section{THE SOUND OF}

\section{TWO HANDS CLAPPINC}

The Education of a Tibetan Buddhist Monk

\section{Georges B.J. Dreyfus}

"A rich and fascinating study of Tibetan monastic life, from an author who is not only a leading scholar of Tibetan Buddhism, but who spent many years as a Buddhist monk."

-Donald Lopez, author of Prisoners of Shangri-La A Philip E. Lilienthal Book in Asian Studies \$60.00 cloth, \$24.95 paper

\section{COLD WAR ORIENTALISM}

Asia in the Middlebrow Imagination, 1945-1961

\section{Christina Klein}

"An extraordinarily interesting study of 'Cold War internationalism.' Klein's brilliant and imaginative reading of such musicals as South Pacific and The King and I enables us to see how culture and geopolitics were woven together to transform the Cold War into today's ethnically diverse and economically interdependent world-within the framework of 'U.S. global expansion.'" -Akira Iriye, author of Clobal Community \$55.00 cloth, \$21.95 paper

\section{SENSORY BIOGRAPHIES}

Lives and Deaths among Nepal's Yolmo Buddhists

\section{Robert Desjarlais}

"One of the most powerful ethnographies in any field that I have read in recent years...a model of anthropological analysis that addresses questions on the cutting edge of the discipline." -Veena Das, author of Critical Events

Ethnographic Studies in Subjectivity

\$54.95 cloth, \$21.95 paper

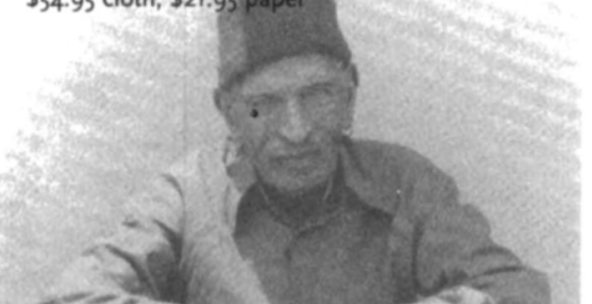

At bookstores or order (800) 822-6657. Www.ucpress.edu UNIVERSITY OF CALIFORNIA PRESS

\section{IMAGINING JAPAN}

The Japanese Tradition and its Modern Interpretation

\section{Robert N. Bellah}

"One of the most original attempts to understand some of the psychological and symbolic roots of the central problems in Japanese history. Bellah masterfully brings together intellectual and institutional dimensions of Japan, making a very important contribution to Japanese Studies."

-S. N. Eisenstadt, author of Japanese Civilization \$60.00 cloth, \$24.95 paper

\section{CHINESE VISIONS OF FAMILY AND STATE, 1915-1953}

Susan L. Glosser

Foreword by Linda Kerber

"Closser illuminates the ideal of the 'small family' and shows how it supplied a cultural repertoire upon which twentieth-century leaders have drawn to promote their own ideas about modernity."

-Susan Mann, Editor of Under Confucian Eyes Asia: Local Studies/Clobal Themes, \$49.95 cloth

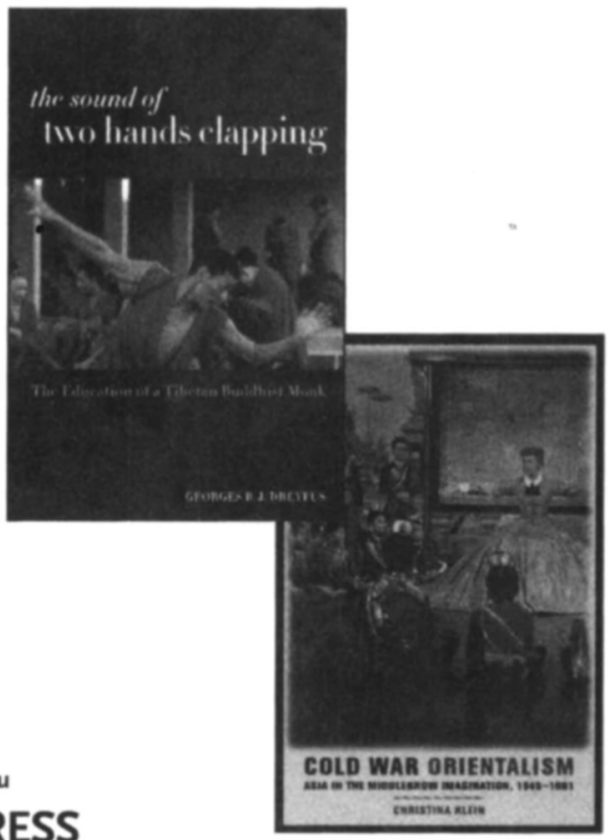




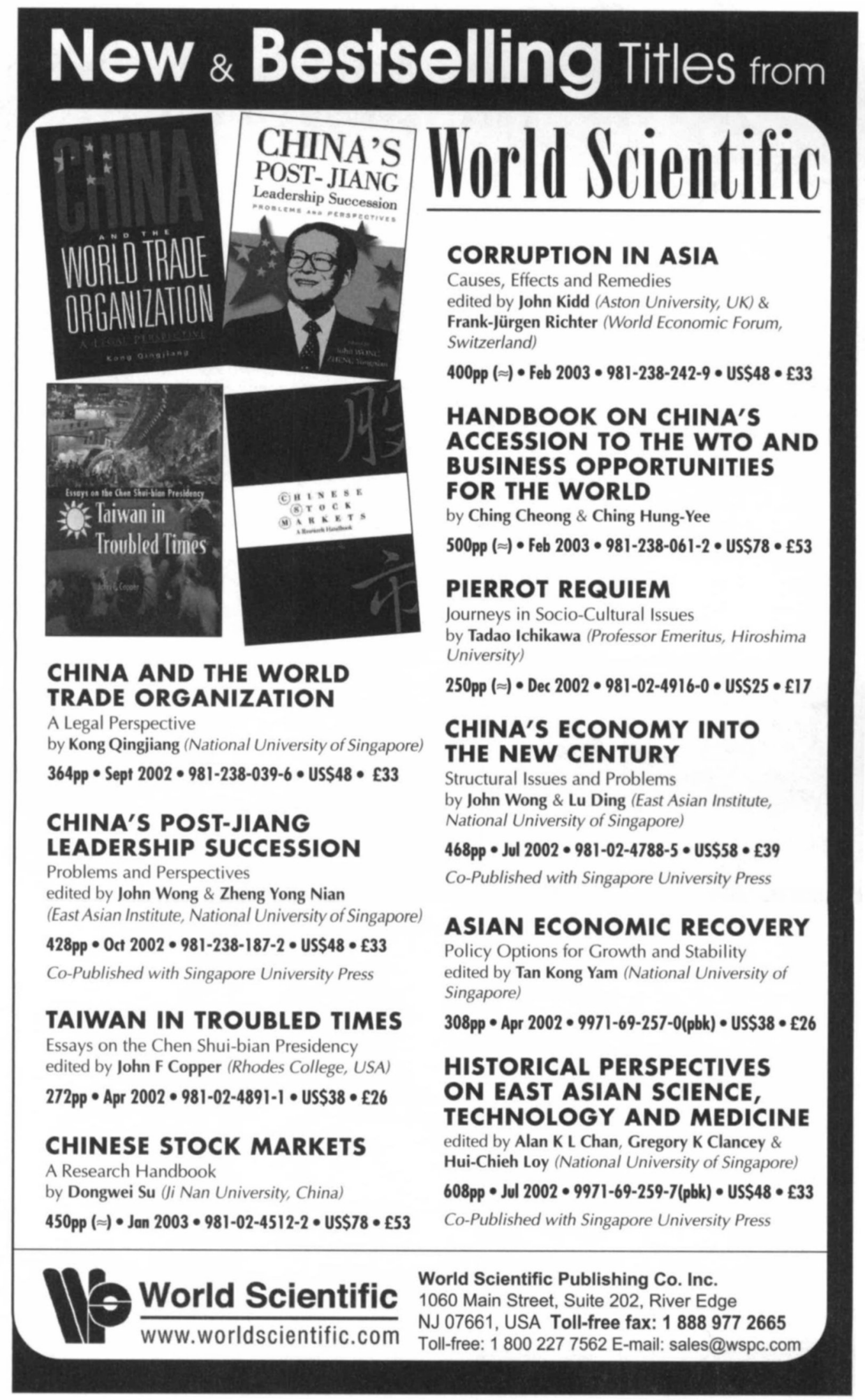




\section{COLUMBIA UNIVERSITY \\ IN THE CITY OF NEW YORK}

Institute Columbia University in the City of New York invites scholars for Scholars who are interested in working in Paris to apply to be fellows at at Reid Hall coming academic year, beginning September 8, 2003. Individuals may apply for year-long or academic term fellowships.

Opened in January 2001 in cooperation with the Maison des Sciences de l'Homme, the Institute offers a setting at which fellows may pursue their individual and collective research while interacting with other scholars in France and throughout Europe.

Preference will be given to scholars in the Humanities, Social Sciences, and related professional disciplines. The Institute encourages collaborative group proposals, although individual applications are welcome. The Institute does not consider applications from doctoral or postdoctoral candidates.

Further information about the Institute and application materials for fellowships may be found at www.columbia.edu/cu/reidhall or may be obtained by calling the Office of the Provost at (212) 854-3813. Applications for 2003-04 fellowships must be received by March 1, 2003.

\section{Introductory Japanese from Houghton Mifflin}

\section{Nakama 1}

Japanese Communication,

Culture, Context

Seiichi Makino

Princeton University

Yukiko Abe Hatasa

University of lowa

Kazumi Hatasa

Purdue University

O1998 - Hardcover -

544 pages $\cdot 0-669-46134-2$

\section{Nakama 2}

Japanese Communication,

Culture, Context

Yukiko Abe Hatasa

University of lowa

Kazumi Hatasa

Purdue University

Selichi Makino

Princeton University

○2000 - Hardcover 576 pages $\cdot 0-669-46137-7$. 0-669-01814-X
This new, proficiency-oriented introductory Japanese program emphasizes practical communication, the development of all four language skills, student interaction, and cultural awareness.

- Hiragana (in Chapters 1-3 of Nakama $\eta$ and katakana (in Chapters 4-6 of Nakama $\eta$ are introduced through unique mnemonic devices that help students learn the characters. Ninety kanji characters are introduced in Chapters 7-12 of Nakama 1, and approximately 290 kanji are presented in Chapters 1-10 of Nakama 2, with stroke-by-stroke writing techniques

- A series of specially created manga precede each chapter dialogue and serve as visual advanced organizers.

- Chapter dialogues present a lively, continuous story line that illustrate typical daily events in Japanese life and provide a realistic context in which to learn vocabulary and grammatical structures.

- Exercises progress from directed practice to a wide range of openended communicative activities that emphasize pair and group work.

- The Houghton Mifflin Japanese Web Site (college.hmco.com) provides additional materials for students and instructors, including links to relevant Internet sites and to a text-specific site developed by the co-authors, Kazumi Hatasa and Yukiko Abe Hatasa.

F HOUGHTON MIFFLIN New Ways to Know

- To request an examination copy, call or fax the Faculty Services Center: Tel: 800/733-1717 - Fax: 800/733-1810, or contact your Houghton Mifflin sales representative.

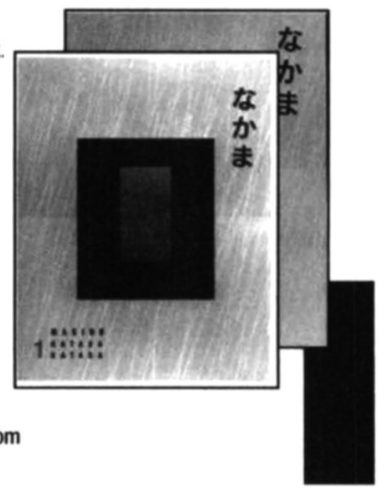




\section{EastBridge Books on Asia}

VISIT US IN NEW YORKCITY AT AAS BOOTH 3105

Ma Jun

China's Water Crisis
hb $\$ 34.95 \quad \mathrm{pb} \$ 24.95$

White Man/Yellow Man trans. Teruyo Shimizu hb $\$ 29.95 \quad \mathrm{pb} \$ 19.95$

Fredrick C. Thomas

To the Mouths of the Ganges

An Ecological and Cultural Journey

hb $\$ 34.95$ pb $\$ 24.95$

\section{River of Life, River of Hope}

Selected Poems of Pak Tu-jin

trans. Edward W. Poitras hb $\$ 29.95$ pb $\$ 19.95$

The Mission Kaleidoscope

Portraits of Six China Missionaries

edited by Kathleen L. Lodwick and Wah

Cheng

hb $\$ 34.95$

$$
\mathrm{pb} \$ 24.95
$$

BettyRugh Elder

Oriole's Song

An American Childhood in Wartorn China hb $\$ 34.95 \quad$ pb $\$ 24.95$

Yi Nam-ho, U Ch'angje, Yi Kwangho

Twentieth Century Korean Literature trans. Youngju Ryu

Edited by Brother Anthony of T'aize

hb $\$ 29.95 \quad \mathrm{pb} \$ 19.95$

Aso Tetsuo

From Shanghai to Shanghai

Memoir of a Japanese Physician in the Pacific War trans Hal Gold

$$
\text { hb } \$ 34.95 \text { pb } \$ 24.95
$$

Tales from the Ming Dynasty

Volume I: The Abbot and the Widow and Other Stories by Ling Meng-chu

trans Ted $\mathrm{H}$. Wang and Chen Chen

hb $\$ 34.95 \quad \mathrm{pb} \$ 22.95$

\section{Robert Stewart}

The Last Bowl of Tea

A Portfolio of Seventeenth Century Chinese Law Cases

The Cry of the Harp hb $\$ 34.95 \quad$ pb $\$ 24.95$

Works by Choi Chong-hui

trans Genell Y. Poitras

hb\$29.95 pb\$19.95

$$
\text { asia@eastbridgebooks.org }
$$

Shaoyi Sun and Li Xun

Voices of China's Sixth Generation of

\section{Filmmakers}

Screening the Urban Landscape

hb $\$ 29.95 \quad \mathrm{pb} \$ 19.95$

Late Qing China and Meiji Japan

Political and Cultural Aspects

edited by Joshua A. Fogel

hb $\$ 35.95$ pb $\$ 25.95$

Tarnished Words

Poetry of Oba Minako

trans Janice Brown

hb $\$ 29.95 \quad$ pb $\$ 19.95$

Brian Burke-Gaffney

Madame Butterfly Unmasked

hb $\$ 32.95 \quad$ pb $\$ 22.95$

Nui Jun

From Yan'an to the World

The Origins of Chinese CP Foreign Relations

trans Steven I. Levine

hb $\$ 34.95 \quad \mathrm{pb} \$ 22.95$

Zi Zhongyun

No Exit?

U.S.-China Relations, 1945-50

trans Zhang Ciyun and Jia Yanli

Foreword by Michael $\mathrm{H}$. Hunt

hb \$34.95 pb\$22.95

David Steinberg

Stone Mirror

Reflections on Contemporary Korea

hb $\$ 24.95 \mathrm{pb} \$ 14.95$

Donald N. Clark

Living Dangerously in Korea

The West in Korea, 1900-1950 hb \$34.95 pb \$24.95

Ben Thompson Cowles

Through the Dragon's Mouth

Journeys into the Yangzi Gorges Second Edition hb $\$ 29.95 \mathrm{pb} \$ 19.95$

Vasili I. Chuikov

Mission to China

Memoirs of a Military Advisor to Chiang Kaishek trans and Introduction by David P. Barrett hb $\$ 29.95 \mathrm{pb} \$ 19.95$

Arthur Smith

\section{Chinese Characteristics}

Introduction by Lydia Liu pb $\$ 14.95$

www.eastbridgebooks.org 


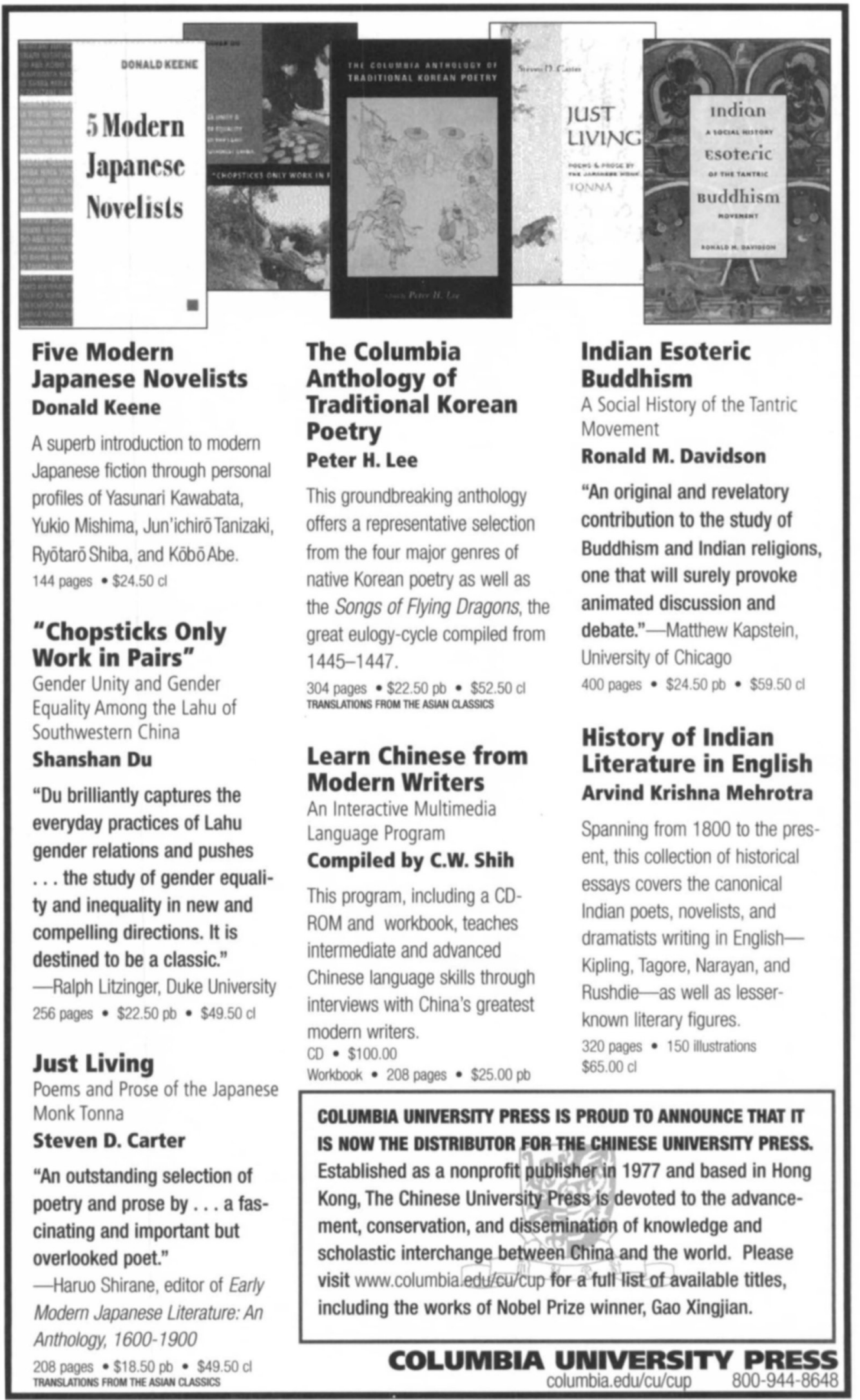




\section{New Paperbacks from the AsSOCIAIION For AsIAN Studies}

Who Can Compete Against the World? Power Protection and Buddhism in Shan Worldview

by Nicola Tannenbaum

In response to continuing demand, AAS has reprinted Tannenbaum's popular ethnographic analysis of Shan religion in paperback. In this unique study, the author questions traditional characterizations of the nature and meaning of Buddhism in lowland mainland Southeast Asia. She explores the role that power-protection plays in structuring the Shan worldviewthereby producing an anthropological interpretation of Shan society and culture that is essential reading for students and scholars of Southeast Asian anthropology, religion, or culture.

ISBN 0-924304-41-3, Paper Edition, 2001,232 pages, List Price: \$23 (AAS Member Price: \$18.50)

\section{Marketing and Social Structure in Rural China}

by G. William SkinNer

The three-part study-originally published in three consecutive issues of the Journal of Asian Studies-has become a classic. The current edition represents the sixth time that this compilation has been reprinted by the Association for Asian Studies. The new edition has several advantages over earlier versions, however. Not only has it been composed anew, but also it incorporates the author's revisions, eliminates errors found in earlier editions, and features an attractive new design that makes the book more visually appealing and easier to use. This sixth edition was created to meet the needs of a new generation of Asian studies scholars and students, as well as to ensure that this classic study remains accessible for all those interested in the study of Asia.

ISBN 0-924304-42-1, 2001 Edition, Approx. 154 pages, List Price: \$1 3 (AAS Member Price: $\$ 10)$

ASSOCIATION FOR ASIAN STUDIES

1021 EAST HURON Street

AnN Arbor, MI 48104

Phone: 734-665.2490; Fax: 734-665.3801

bookorder@aAsiansI.ORG 


\section{PERS PETIVES ON GHINA}

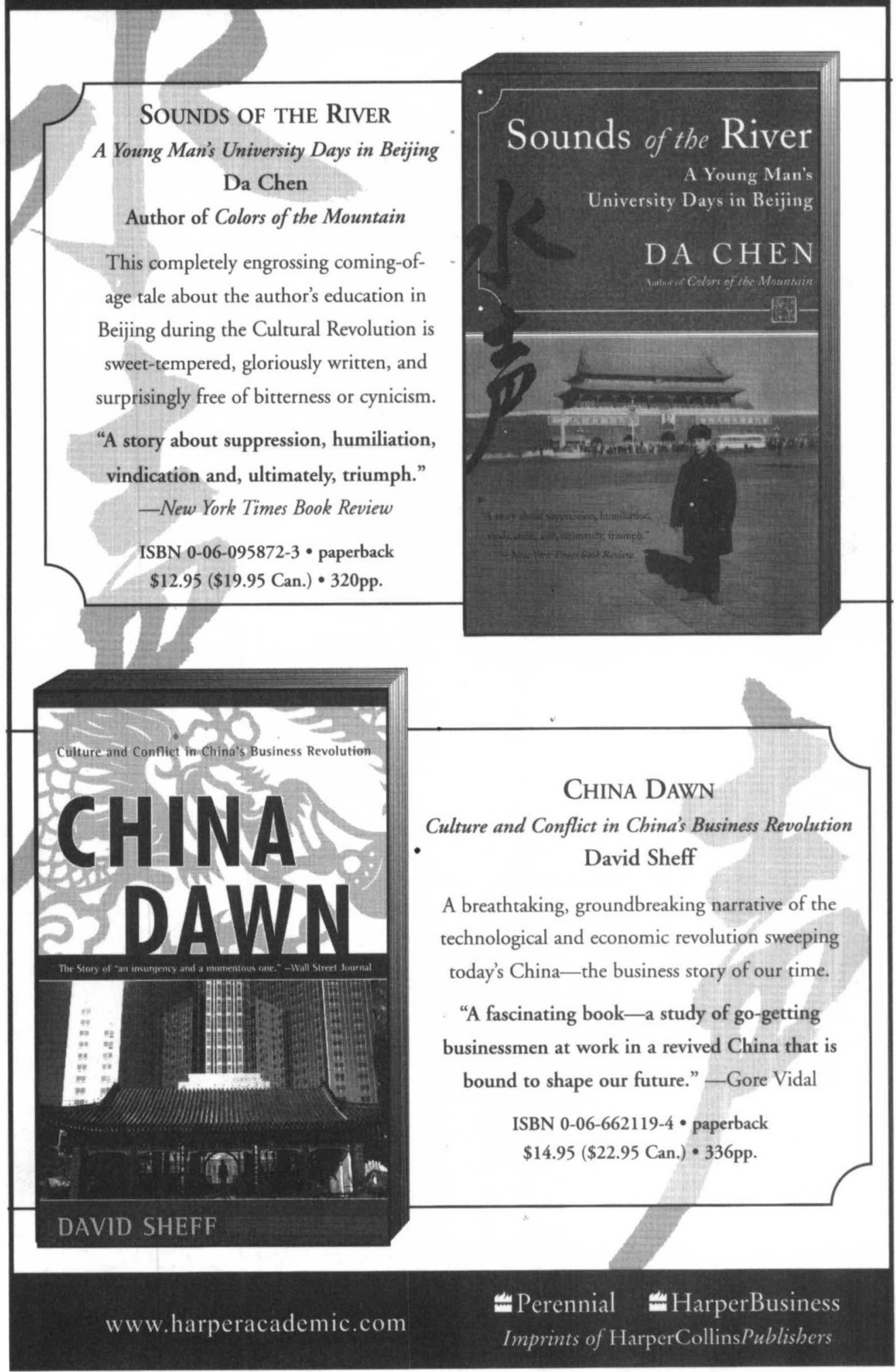




\section{New from $\mathrm{OXFORD}$}

\section{Forthcoming! \\ The Goddesses' Henchmen \\ Gender in Indian Hero Worship LINDSEY HARLAN}

In this book, Lindsey Harlan explores the idea of the Rajput hero. She is particularly interested in the role played by gender in stories about heroes and in their worship. Ultimately she shows how heroic traditions encapsulate and express ideals of perfection and masculinity, defined most visibly against the backdrop of domesticity and femininity. More broadly she argues that heroes reflect ever-changing valuations of history, and serve as sources of inspiration for facing contemporary challenges (domestic, communal, national) and concerns about the future.

$288 \mathrm{pp}$. paper $\$ 25.00 /$ doth $\$ 65.00$

\section{India}

\section{Development and Participation}

\section{JEAN DREZE and AMARTYA SEN}

This book explores the role of public action in eliminating deprivation and expanding human freedoms in India. The analysis is based on a broad and integrated view of development, which focuses on well-being and freedom rather than the standard indicators of economic growth. The authors place human agency at the centerstage, and stress the complementary roles of different institutions (economic, social, and political) in enhancing effective freedoms.

$532 \mathrm{pp}$. paper $\$ 24.95 /$ cloth $\$ 72.00$

\section{Dowry Murder}

The Imperial Origins of a Cultural Crime VEENA TALWAR OLDENBURG

"A strong, contentious book on an intellectually and socially hot topic, Dowry Murder offers a rich complex answer to the question: What are the causes of voilence against women in India, of female infanticide, 'dowry' deaths, and battering?"

- Susanne Hoeber Rudolph, Professor of Political Science, University of Chicago

$288 \mathrm{pp}$. paper $\$ 18.95 /$ eloth $\$ 55.00$

\section{The Japanese Way of Justice}

Prosecuting Crime in Japan

\section{DAVID T. JOHNSON}

The Japanese Way of Justice makes an outstanding contribution to both scholarship on the Japanese criminal justice system and comparative sociolegal research in general. The author communicates his thoughts so well that anyone generally interested in criminal prosecution will find it of interest."

$$
\begin{aligned}
& \text {-Law and Politics Book Review } \\
& \text { (Studies on Law and Social Control) } \\
& 344 \mathrm{pp} . \quad \$ 45.00
\end{aligned}
$$

\section{Dissenters and Mavericks \\ Writings About India in English, 1765-2000 MARGERY SABIN}

Offering fresh and provocative interpretations of both well-known and unfamiliar texts-from colonial writers such as Horace Walpole and Edmund Burke to twentieth-century Indian writers such as Nirad Chaudhuri, V.S. Naipaul, and Pankaj Mishra-the book proposes a controversial challenge to prevailing academic methodology in the field of postcolonial studies.

$256 \mathrm{pp}$. $\$ 29.95$

\section{Calling Back the Spirit}

Music, Dance, and Cultural Politics in Lowland South Sulawesi

\section{R. ANDERSON SUTTON}

Calling Back the Spirit describes how, in the face of Indonesian and foreign cultural pressures, the Makassarese people of Sourh Sulawesi are defending their local spirit through music and dance. The book examines the ways performers in this corner of Indonesia seek to empower local music and dance in a changing environment.

$296 \mathrm{pp}$. $\$ 65.00$

\section{Shivaji}

Hindu King in Islamic India

\section{JAMES W. LAINE}

Shivaji was a 17 th-century hero in western India, where his legend is well known and an important part of Hindu nationalist ideology. His legend expresses deeply held convictions about what Hinduism is, and how it is opposed to Islam. James Laine traces the origin and development of the Shivaji legend, examining its meaning for those who have composed and read it, and painting a complex picture of the past four centuries of Hindu-Muslim relations.

$144 \mathrm{pp} . \quad \$ 35.00$

\section{New in Paperback!}

\section{Gandhi's Passion}

\section{The Life and Legacy of Mahatma Gandhi STANLEY WOLPERT}

"There have been many books about Gandhi, including those by the subject himself. What has always been needed is a full, literate account by someone closely familiar with India and Indian history who is also an accomplished writer and historian. This, we now have. Henceforth no one can claim knowledge of one of the greatest and most enigmatic figures of the last century who hasn't read it. And, I might add, no one will read it without interest and approval." -John Kenneth Galbraith

336 pp. paper $\$ 17.95 /$ cloth $\$ 35.00$ 


\section{ASIAN STUDIES \\ NEW FROM CHICAGO}
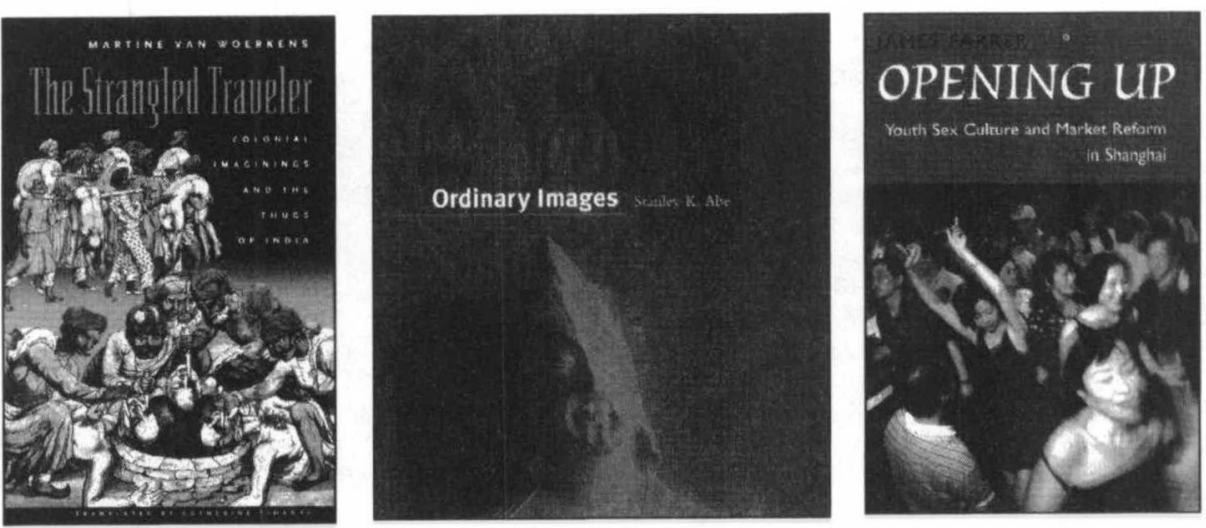

The Strangled Traveler

Colonial Imaginings and the

Thugs of India

\section{Martine van Woerkens}

Translated by Catherine Tihanyi

"An insightfully provocative book, at once erudite and entertaining, with a sophisticated critical and analytic framework for the lurid material out of which it is constructed. I am confident that the English translation of this compelling piece of scholarship will be a valued contribution to Indian studies." - Lee Siegel, author of Love in a Dead Language

PAPER \$24.00

\section{OrdinaRY ImAges}

\section{Stanley K. Abe}

"In this important and timely book, Stanley Abe takes on one of the more formidable problems of premodern Chinese studies, the task of exploring the gap between two incommensurate bodies of data: text and image. His point of attack is that spot where the gap is the widest, that between elite religious writings and 'ordinary' images of devotion. ... The images he has collected are outstanding and very important in their own right"-Stephen R. Bokenkamp, Indiana University

408 PAGES, 230 HALFTONES, 5 MAPS, 20 LINE dRAWINGS СLотн $\$ 65.00$

\section{Opening UP}

Youth Sex Culture and Market Reform in Shanghai

\section{James Farrer}

“Opening Up links China's retreat from socialism to the emergence of a newly sexualized public life. The voices here of urban Shanghai youth tell the story of sexual revolution, but it is Farrer who molds their riveting individual conversations about sexual initiation and romantic fantasies into a compelling narrative of an entire generation's coming of age."

-Deborah Davis, Yale University

PAPER $\$ 19.00$

\section{Measuring Judicial INDEPENDENCE}

The Political Economy

of Judging in Japan

\section{J. Mark Ramseyer}

\section{and Eric B. Rasmusen}

In this book, J. Mark Ramseyer and Eric B.

Rasmusen use the latest statistical techniques to examine whether (and if so, to what extent) Japanese politicians manipulate the careers of lower court judges to political advantage.

\section{CLOTH \$45.00}




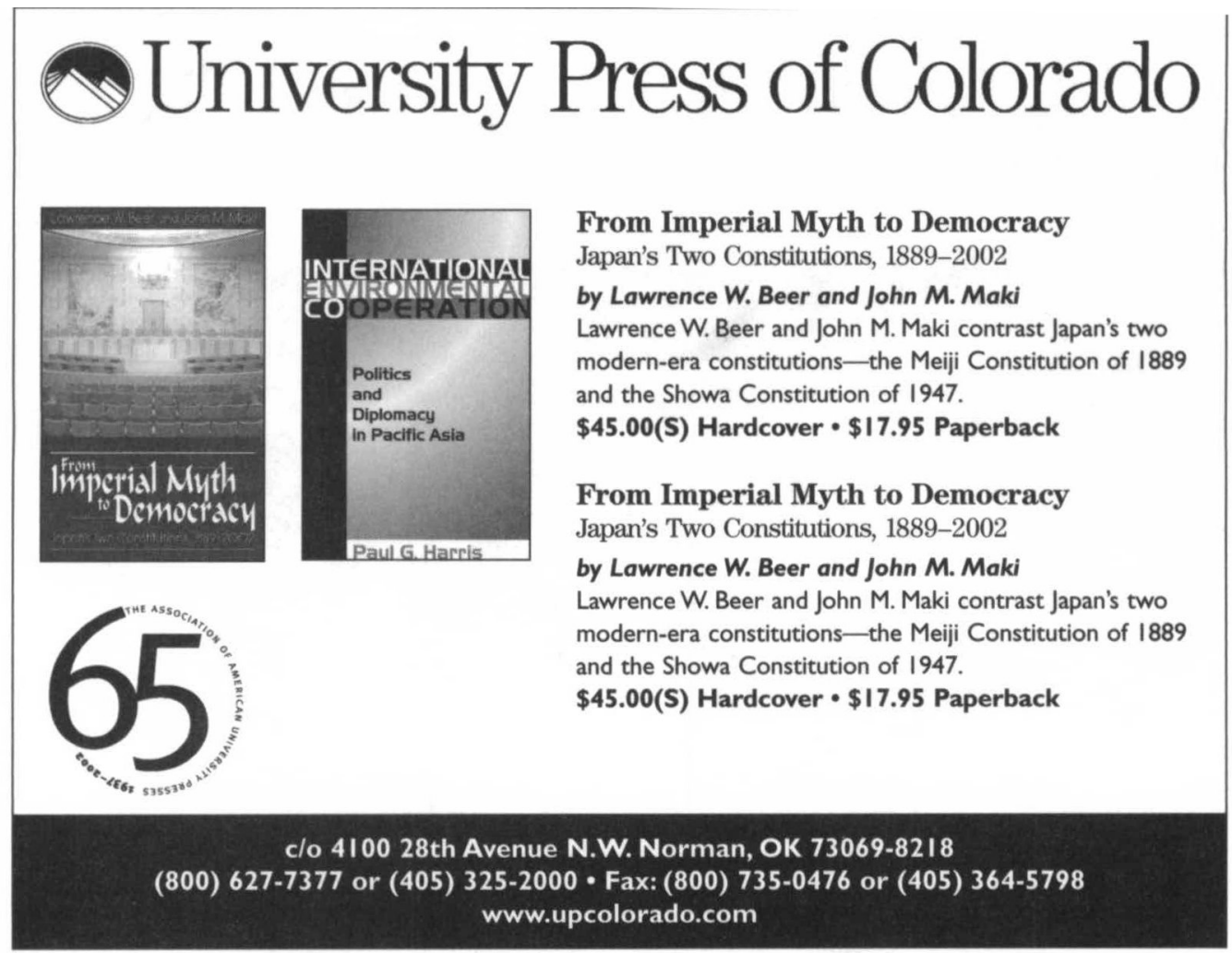

\section{MUSEUM OUALITY EXHIBITS}

"MY LIFE IS MY MESSAGE"-40 panels $(2$ ' $\times$ 4') of photographs with captions on the life of Mahatma Gandhi.

“INDIA-THE PEOPLE AND THEIR LAND"-more than 100 color photographs taken over 40 years by Beatrice Pitney Lamb.

"BEAUTY IN STONE"-Hindu, Buddhist, and Islamic architecture of India, color photographs by Beatrice Pitney Lamb.

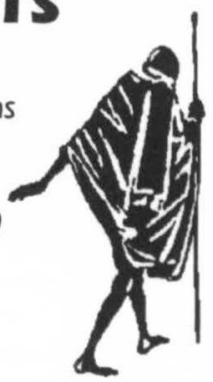

Also smaller portable exhibit (sent by mail), video-cassettes (including biographical documentaries of Gandhi), and other resources available for loan.

Undergraduate-level CORRESPONDENCE COURSE on Gandhi (study materials from the Gujarat Vidyapith University in India, founded in 1920).

THE GANDHI MEMORIAL CENTER

\section{P.O. Box 9515}

Washington, D.C. 20016

Phone: (301) 229-3871

Website: www.gandhimc.org

Email: gandhimc(aerols.com 


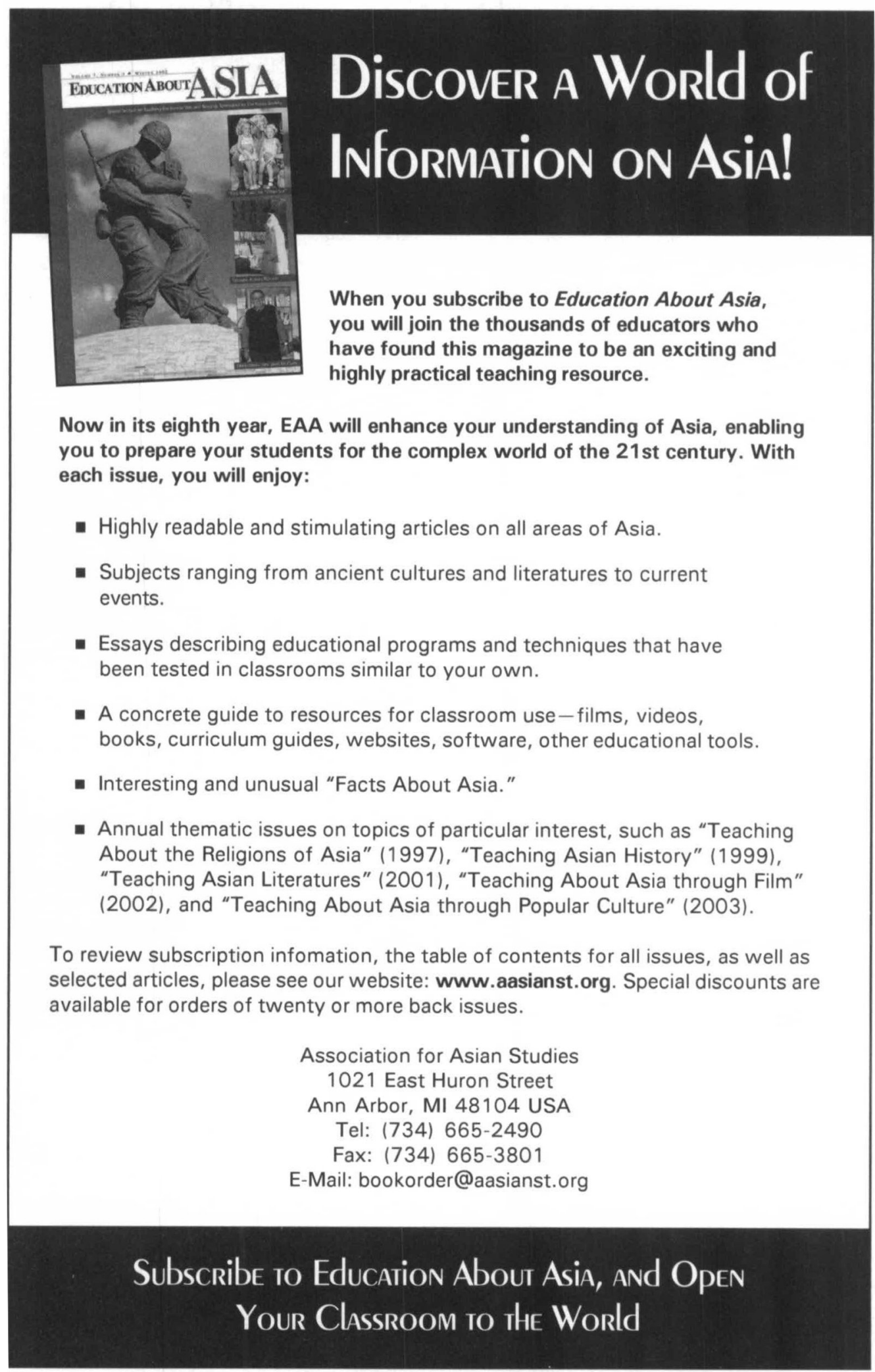




\section{The Association for Asian Studies, Inc.}

Officers of the Association. President-DAVId LudDEN, University of Pennsylvania. Vice President-James "Woody" Watson, Harvard University. Past President-Charles KeYes, University of Washington. Past-Past President-PETER Duus, Stanford University.

Board of Directors. President, Vice President, Past President, and Past-Past President, as listed above. Editor of the Journal of Asian Studies-ANN B. WALTNER, University of Minnesota. China and Inner Asia Council-JeAN OI, Stanford University. Northeast Asia Council-LINDA LEWIS, Wittenberg University. South Asia Council-MarTHA SelBy, University of Texas, Austin. Southeast Asia Council-RITA SmITH KIPP, Kenyon College. Council of Conferences-Robert Entenmann, St. Olaf University. Program Committee Chair-Mary STEEDLY, Harvard University.

Staff of the Association. Executive Director-Michael PAschal. Comptroller-CAROL J. Kelingos. Publications Manager-Ann W. Beard. Conference Manager-Karen F. Fricke. Membership Manager-JOAN DEWEY. Publications and Website Coordinator-JONATHAN Wilson. Fulfillment Coordinator-Anne Arizala. Accounts Receivable-Vienna Gordon. Office Assistant-KaARINA Quinnell.

Sponsoring Institutions. University of Michigan and University of Minnesota.

\section{EDITORIAL AND SUBSCRIPTION INFORMATION}

The Journal of Asian Studies (ISSN 0021-9118), known until September 1956 as the Far Eastern Quarterly, is published by the Association for Asian Studies (formerly the Far Eastern Association) in February, May, August, and November. The annual subscription rate for the Journal is $\$ 70$ for U.S. addresses and $\$ 80$ for non-U.S. addresses, with postage included for delivery by Periodicals Postal Class. (The subscriber has the option of paying extra for delivery by U.S. First Class or Foreign Airmail.) Single issues published after February 1974 are available from the Secretariat of the Association. Issues published prior to 1958 may be purchased from A.M.S. Reprints, 56 East 13th Street, New York, NY 10003 USA. Bell \& Howell, 300 North Zeeb Road, Ann Arbor, MI 48106 USA offers all volumes on either microfilm or microfiche.

All correspondence regarding memberships, subscriptions, advertising, claims, reprints, offprints, and similar issues shoud be addressed to the office of the Association for Asian Studies, 1021 East Huron Street, Ann Arbor, Michigan 48104 USA. For information on subscriptions, claims, or advertising, please contact the AAS Publications Manager, Ann W. Beard, at abeard@aasianst.org. For questions involving memberships, write to the Membership Manager, Joan Dewey, at jdewey@aasianst.org. To learn more about the Association, its publications, and its other activities, see the AAS website: www.aasianst.org.

\section{AAS ANNUAL MEETING \\ The Fifty-Fifth Annual Meeting of the Association for Asian Studies will be held at the New York Hilton Hotel \\ in New York, NY, March 27-30, 2003. EXPECTEd AtTEndance: $\mathbf{3 , 1 0 0}$}

For further information, contact: Association for Asian Studies, 1021 East Huron Street, Ann Arbor, Ml 48104 USA

Phone: (734) 665-2490; Fax: (734) 665-3801; E-Mail: annmtg@ aasianst.org. 


\section{NEW FOR THE CLASSROOM}

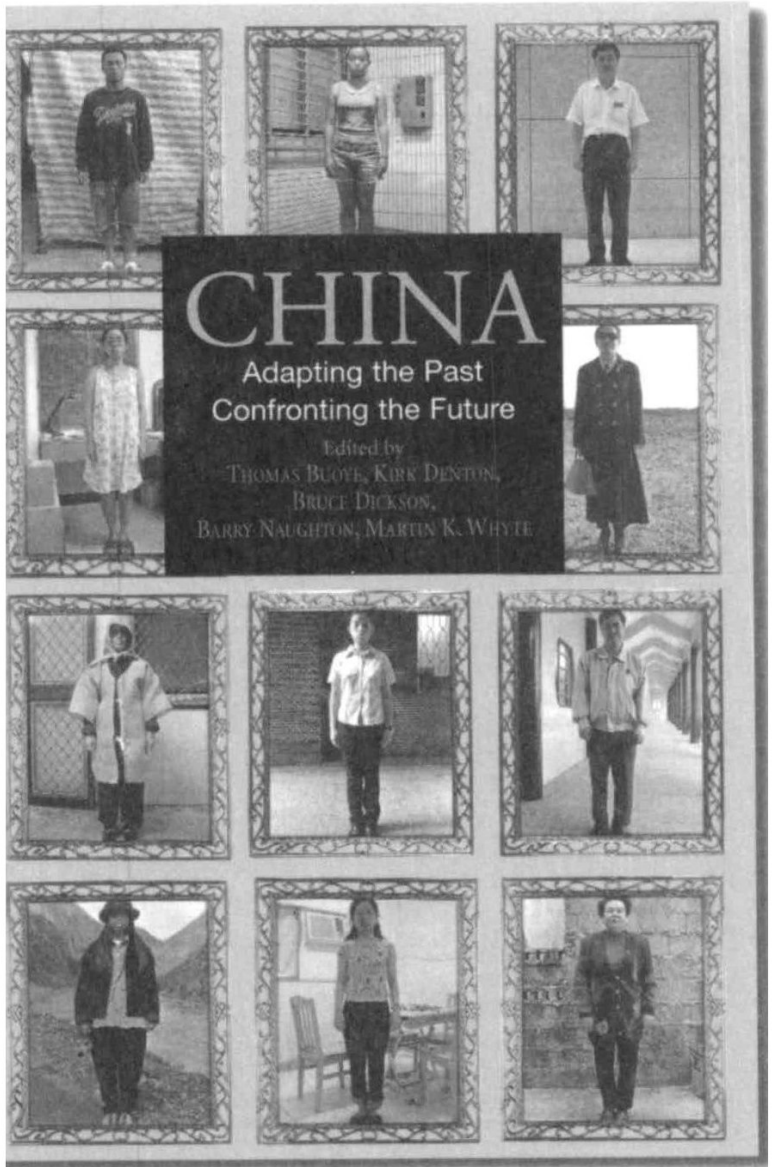

CHINA:

Adapting the

Past, Confronting the Future

Edited by

THOMAS BUOYE, KIRK DENTON, BRUCE DICKSON, BaRRY NAUGHTON, MARTIN K. WhYTE

650 pages / paper $/ \$ 37.00$

Combines original essays by leading experts with excerpts from primary sources, the latest scholarship, Chinese literature, and Western media reports to provide a comprehensive textbook on contemporary China. Covers Geography \& History, Culture, Politics, Economy, Society, and Future Trends.

Also available:

STUDY GUIDE to CHINA: Adapting the Past, Confronting the Future

BY THOMAS BUOYE

Includes an extensive annotated list of video and on-line resources, as well as a list of readings in the text, an overview of the materials, learning objectives, key concepts in each unit, and review questions. 
LISA N. TRIVEDI

Visually Mapping the "Nation": Swadeshi Politics in Nationalist India, 1920-1930

\author{
DEBORAH WINSLOW \\ Potters' Progress: Hybridity and Accumulative \\ Change in Rural Sri Lanka
}

CHARLES K. ARMSTRONG

The Cultural Cold War in Korea, 1945-1950

FRANK N. PIEKE

The Genealogical Mentality in Modern China

KIDDER SMITH

Sima Tan and the Invention of Daoism, "Legalism," et cetera 